\title{
Economic Evaluation of Community-Based HIV Prevention Programs in Ontario: Evidence of Effectiveness in Reducing HIV Infections and Health Care Costs
}

\author{
Stephanie K. Y. Choi ${ }^{1,2}$ - David R. Holtgrave ${ }^{4} \cdot$ Jean Bacon $^{1} \cdot$ Rick Kennedy $^{5}$.

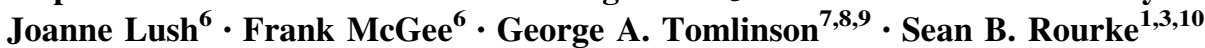

Published online: 8 July 2015

(c) The Author(s) 2015. This article is published with open access at Springerlink.com

\begin{abstract}
Investments in community-based HIV prevention programs in Ontario over the past two and a half decades are assumed to have had an impact on the HIV epidemic, but they have never been systematically evaluated. To help close this knowledge gap, we conducted a macro-level evaluation of investment in Ontario HIV prevention programs from the payer perspective. Our results showed that, from 1987 to 2011, province-wide community-based programs helped to avert a total of $16,672 \mathrm{HIV}$ infections, saving Ontario's health care system approxi-
\end{abstract}

Sean B. Rourke

sean.rourke@utoronto.ca

1 The Ontario HIV Treatment Network, Toronto, Ontario, Canada

2 Faculty of Medicine, University of Toronto, Toronto, Ontario, Canada

3 Li Ka Shing Knowledge Institute of St. Michael's Hospital, 30 Bond St., Toronto, Ontario M5B 1W8, Canada

4 Department of Health, Behaviour and Society, Bloomberg School of Public Health, John Hopkins University, Baltimore, MD, USA

5 The Ontario AIDS Network, Toronto, Ontario, Canada

6 AIDS Bureau, Ontario Ministry of Health and Long-term Care, Toronto, Ontario, Canada

7 Institute of Health Policy, Management and Evaluation, University of Toronto, Toronto, Ontario, Canada

8 Division of Biostatistics, Dalla Lana School of Public Health, University of Toronto, Toronto, Ontario, Canada

9 University Health Network, Toronto, Ontario, Canada

10 Department of Psychiatry, Faculty of Medicine, University of Toronto, Toronto, Ontario, Canada mately $\$ 6.5$ billion Canadian dollars (range 4.8-7.5B). We also showed that these community-based HIV programs were cost-saving: from 2005 to 2011, every dollar invested in these programs saved about $\$ 5$. This study is an important first step in understanding the impact of investing in community-based HIV prevention programs in Ontario and recognizing the impact that these programs have had in reducing HIV infections and health care costs.

Resumen En Ontario, inversiones de programas para prevención de VIH con base comunitaria, se han llevado acabo, durante las últimas dos décadas. Estos esfuerzos se han presumido como efectivos, aunque sin por el momento, se hayan realizado evaluaciones sistemáticas. Para ayudar a cerrar la ausencia de conocimiento, se condujo una evaluación a nivel macro, sobre la inversión de programas de prevención de VIH en Ontario, desde la perspectiva de los contribuidores de impuestos. Los resultados muestran que: desde 1987 hasta el 2011, los programas comunitarios de prevención provinciales ayudaron a prevenir un total de 16 , 672 (nuevas) infecciones de VIH, ahorrándole al sistema de salud de Ontario aproximadamente $\$ 6.5$ billones de dólares (rango: \$4.8 B-\$7.5 B). También mostramos que los programas comunitarios de prevención, desde el 2005 al 2011, ahorraron de cada dólar invertido, $\$ 5$ dólares (CAD). Este estudio es un paso importante para el entendimiento del impacto de la inversión en programas con base comunitaria, y reconoce el impacto que estos programas han tenido en la reducción de infecciones de VIH y el costo en el cuidado de la salud, en Ontario.

Keywords Macro-level analysis - Program evaluation · HIV · Primary prevention · Community action · Return on investment 


\section{Introduction}

The economic burden of HIV infection is substantial. In the United States, on average, the life-time cost per case is estimated as ranging from $\$ 253,000$ to $\$ 402,000$ (USD) [1]. Over the past two and a half decades, communitybased programs and behavioural prevention strategies have played key roles in HIV and sexually transmitted infection prevention in Canada, the United States, Australia, the United Kingdom and elsewhere. A significant body of evidence has demonstrated that community-based and behavioural interventions are effective in: reducing risky sexual behaviour and the incidence of sexually transmitted infections in high-risk populations [2-7]; increasing condom use [8-10]; increasing knowledge of HIV transmission and prevention [7]; improving adherence to antiretroviral therapy [11]; and improving retention to care and treatment [6, 12]. Since the beginning of the HIV epidemic, Ontario's HIV prevention strategies have relied heavily on province-wide, community-based HIV organizations to deliver prevention programs, educate populations and communities at-risk, and develop meaningful relationships with the community $[13,14]$. In its prevention strategies, the province has strategically taken into account the impact of stigma, culture and human rights, as well as the social, behavioural and structural factors that affect HIV risk [13, 14].

Though many community-based behavioural HIV prevention programs have been shown to be successful, their outcomes often rely on self-reported behaviour change. The link between investments in these programs and the actual reduction of HIV infections is not well understood. However, understanding the link is vital for health planners and policy decision makers trying to determine whether allocating scarce resources to these programs is good value for money.

The major difficulty in understanding the impact of investment is the long causal pathway that runs between investments made and actual reductions in HIV infections. The impact of investment may take many years and, along the way, there are many confounding factors that might influence final outcome(s). Despite these difficulties, researchers at the U.S. Centers for Disease Control and Prevention (CDC) have created methodologies and models to evaluate the economic impact of HIV prevention programs and to provide support in recent years for funding resource allocation in the U.S. [15-21]. A correlation analysis showed that U.S. investments in HIV prevention appear to be correlated with the reduction of HIV incidence from 1985 to 2006 [22]. Another U.S. analysis found that investments in HIV prevention programs between 1991 and 2006 helped to avert 361,878 new HIV cases and saved the
U.S. health care system $\$ 130$ billion [17]. A model-based evaluation study has shown that most non-biomedical, community-based and behavioural interventions are cost saving [23]. An optimal portfolio of cost-saving interventions could reduce new HIV cases by $34 \%$ and save $\$ 5$ billion (USD) over the next 20 years [23]. Substantially scaling up cost-effective HIV prevention programs in the future may help avert new HIV cases and reduce costs in the U.S. and other countries [18-21].

To our knowledge, no similar evaluation analysis has been done for province-wide, community-based programs for HIV prevention in Ontario; there has also been no analysis of the level of investment required to have an impact. We took a first step to evaluate community-based HIV prevention programs and strategies at the macro level in the social and political context of Ontario, Canada. We did this by: retrospectively quantifying the historical impacts of community-based programs for HIV prevention in Ontario from 1987 to 2011; estimating the economic impacts of these programs from the payer perspective; and evaluating the financial return on investment of Ontario's community-based programs for HIV prevention.

\section{Materials and Methods}

To evaluate the historical and economic impacts of Ontario's community-based programs, we applied wellestablished methods used to evaluate the publicly-funded U.S. investments in HIV prevention strategies [15-21]. This study was based on aggregate data, so did not require institutional ethical approval. All data used in this study were obtained through approvals from the provincial and federal governments.

\section{Ontario's Province-Wide Community-Based HIV Programs}

In Ontario, community-based HIV organizations are nonprofit organizations governed by independent boards, established specifically to provide HIV prevention, education, outreach and support services to people living with HIV or to populations at risk of HIV (e.g., gay men, people who inject drugs, people from countries where HIV is endemic, and Indigenous people). It is important to include funding for support services for people living with HIV within prevention programming because of the critical impact that education and support have on onward transmission. Table 1 describes the major key non-biomedical and behavioural interventions for HIV and sexually transmitted infections (STIs) provided by community-based HIV organizations in Ontario. It also cites the literature on 
Table 1 Main non-biomedical interventions for HIV and sexually transmitted infection prevention provided by community-based AIDS service organizations and a summary of corresponding evidence of the effectiveness of these interventions

\begin{tabular}{ll}
\hline Non-biomedical intervention & Target populations \\
\hline $\begin{array}{l}\text { Individual-, group-, and community- } \\
\text { level education, outreach, and } \\
\text { community campaigns that }\end{array}$ & $\begin{array}{c}\text { People living with HIV } \\
\text { promote risk-behaviour reduction }\end{array}$ \\
& men who have sex with \\
& men \\
& Indigenous people \\
& African, Caribbean and \\
& Black Ontarians \\
& Women at-risk (who \\
& engage in activities with a \\
& high risk of exposure to \\
& HIV, or with priority \\
& populations) \\
Promote HIV medication adherence & People living with HIV
\end{tabular}

Social support and social inclusion

Needle and syringe programs, safer inhalation programs, harm reduction outreach programs, and community development for people who use drugs

Education and support for reduction of risky HIV transmission behaviour

Injection drug users / people who use drugs $\begin{array}{ll}\begin{array}{l}\text { Examples of Ontario's community- } \\ \text { based programs }\end{array} & \begin{array}{l}\text { Evidence of effectiveness in current } \\ \text { literature }\end{array}\end{array}$

Prevention/education activities targeted to high-risk populations (e.g., group workshops/ presentations in varying locations and one-on-one education through outreach activities)

Community campaigns such as the HIV Stigma campaign, Our Agenda, Keep It Alive for African, Caribbean and Black communities etc.

Clinical counseling

Case management

Support sessions for HIV symptoms management, treatment/ medication Adherence

Clinical counseling

Support sessions for disclosure, emotional well-being, harm reduction, physical health, employment services, relationships/social supports, financial counseling, housing, stigma/discrimination, employment services, wellness checks

\section{Bereavement services}

Distribution of safer injection equipment: cookers, filters, needles, sharps containers, swabs, ties/tourniquets, vitamin C/acidifiers, water for injection, and safer inhalation equipment

Harm reduction activities, outreach and education programs (e.g. safer injection, safer inhalation, and safer sex practices to reduce HIV risk and transmission)

Prevention, education, and outreach

Gay, bisexual and other activities men who have sex with men

Indigenous people

African, Caribbean and Black Ontarians

People who use drugs

Women at-risk (who engage in activities with a high risk of exposure to HIV, or with priority populations)
Reduce odds of unprotected anal intercourse by $27-43 \%$, and increase odds of condom use by $81 \%$ [8-9]

Increase HIV medication adherence behaviour and reduce HIV viral loads among people living with HIV [11]

A high level of social support is associated with fewer risky sexual behaviours [5]

Support programs can achieve a high level of retention in care $(91.4 \%)$ over a 4-year follow-up [6]

Exposure to needle and syringe programs was associated with reduction of HIV transmission (pool effect size: $0.4,95 \%$ CI 0.22-0.81) [2]

Community outreach programs for injection drug users were effective [4]

Education and support programs significantly reduced unprotected sex (OR 0.57, $95 \%$ CI 0.40-0.73), and incidence of sexually transmitted disease (OR 0.20, $95 \%$ CI 0.05-0.73) [3]

Men living in geographic regions of Ontario with HIV prevention programming had unprotected homosexual intercourse with both casual and regular partners significantly less frequently [60] 
Table 1 continued

\begin{tabular}{|c|c|c|c|}
\hline Non-biomedical intervention & Target populations & $\begin{array}{l}\text { Examples of Ontario's community- } \\
\text { based programs }\end{array}$ & $\begin{array}{l}\text { Evidence of effectiveness in current } \\
\text { literature }\end{array}$ \\
\hline $\begin{array}{l}\text { Mass media programs for HIV } \\
\text { prevention }\end{array}$ & $\begin{array}{l}\text { People living with HIV } \\
\text { Gay, bisexual and other } \\
\text { men who have sex with } \\
\text { men } \\
\text { Indigenous people } \\
\text { African, Caribbean and } \\
\text { Black Ontarians } \\
\text { People who use drugs } \\
\text { Women at-risk (who } \\
\text { engage in activities with a } \\
\text { high risk of exposure to } \\
\text { HIV, or with priority } \\
\text { populations) }\end{array}$ & $\begin{array}{l}\text { Mass media campaigns, e.g. Keep It } \\
\text { Alive, HIV Stigma, Our Agenda }\end{array}$ & $\begin{array}{l}\text { Increases in condom use [effect size } \\
\text { (d): } 0.25,95 \% \text { CI } 0.18-0.31 \text { ] } \\
\text { knowledge of HIV transmission } \\
\text { (d: } 0.30,95 \% \text { CI } 0.18-0.41) \\
\text { knowledge of HIV prevention (d: } \\
0.39,95 \% \text { CI } 0.25-0.52 \text { ) [7] }\end{array}$ \\
\hline $\begin{array}{l}\text { Mass condom, and safer sex } \\
\text { materials distribution }\end{array}$ & $\begin{array}{l}\text { People living with HIV } \\
\text { Gay, bisexual and other } \\
\text { men who have sex with } \\
\text { men } \\
\text { Indigenous people } \\
\text { African, Caribbean and } \\
\text { Black Ontarians } \\
\text { People who use drugs } \\
\text { Women at-risk (who } \\
\text { engage in activities with a } \\
\text { high risk of exposure to } \\
\text { HIV, or with priority } \\
\text { populations) }\end{array}$ & $\begin{array}{l}\text { Distribution of condoms, lubricant } \\
\text { and dental dams }\end{array}$ & $\begin{array}{l}\text { Increased condom use (OR 1.8, } \\
95 \% \text { CI 1.51-2.17), condom } \\
\text { acquisition (OR 5.4, } 95 \% \text { CI } \\
1.86-15.66) \text {, and reduced } \\
\text { incidence of sexually transmitted } \\
\text { disease (OR } 0.69,95 \% \text { CI } \\
0.53-0.91)[10]\end{array}$ \\
\hline $\begin{array}{l}\text { Practical assistance programs } \\
\text { (includes distribution of practical } \\
\text { assistance items) }\end{array}$ & $\begin{array}{l}\text { People living with HIV } \\
\text { Gay, bisexual and other } \\
\text { men who have sex with } \\
\text { men } \\
\text { Indigenous people } \\
\text { African, Caribbean and } \\
\text { Black Ontarians } \\
\text { People who use drugs } \\
\text { Women at-risk (who } \\
\text { engage in activities with a } \\
\text { high risk of exposure to } \\
\text { HIV, or with priority } \\
\text { populations) } \\
\text { People affected by HIV }\end{array}$ & $\begin{array}{l}\text { Practical assistance programs, e.g. } \\
\text { access to food programs, access to } \\
\text { complementary therapies, } \\
\text { emergency financial assistance, } \\
\text { assistance accessing provincial } \\
\text { drug payment programs, child care } \\
\text { subsidy, clothing, household } \\
\text { items, help with transportation, } \\
\text { assistance with tax, insurance, or } \\
\text { legal information }\end{array}$ & $\begin{array}{l}\text { Support program can achieve a high } \\
\text { retention of care }(91.4 \%) \text { over a } \\
\text { 4-year follow-up [6] }\end{array}$ \\
\hline $\begin{array}{l}\text { Linkage to HIV care, Ontario's } \\
\text { testing programs, HIV supportive } \\
\text { case management, and clinical } \\
\text { counseling }\end{array}$ & People living with HIV & $\begin{array}{l}\text { Case management } \\
\text { Support sessions that focus on } \\
\text { connection to HIV care, retention } \\
\text { in HIV care, HIV management, } \\
\text { supporting clients to make/keep/or } \\
\text { travel to medical appointments, } \\
\text { referrals to HIV care, testing or } \\
\text { treatment, or accompanying } \\
\text { clients to medical appointments. } \\
\text { Anonymous point-of-care testing as } \\
\text { well as standard blood draw HIV } \\
\text { testing-anonymous, nominal, } \\
\text { non-nominal/coded } \\
\text { Clinical counseling services }\end{array}$ & $\begin{array}{l}\text { Case management and community } \\
\text { engagement program increased } \\
\text { likelihood of retaining in care (OR } \\
4.13,95 \% \text { CI 1.93-8.85) [12] } \\
\text { Community-based approach } \\
\text { increased uptake of HIV testing } \\
\text { and counseling (RR 10.65, } 95 \% \\
\text { CI } 6.27-18.08 \text { ) and increased } \\
\text { proportion of first-time testers (RR } \\
1.23,95 \% \text { CI 1.06-1.42) [55] } \\
\text { Support programs can achieve a } \\
\text { high retention of care (91.4 \%) } \\
\text { over a 4-year follow-up [6] }\end{array}$ \\
\hline
\end{tabular}


Table 1 continued

\begin{tabular}{|c|c|c|c|}
\hline Non-biomedical intervention & Target populations & $\begin{array}{l}\text { Examples of Ontario's community- } \\
\text { based programs }\end{array}$ & $\begin{array}{l}\text { Evidence of effectiveness in current } \\
\text { literature }\end{array}$ \\
\hline $\begin{array}{l}\text { Increase awareness of use of post- } \\
\text { exposure prophylaxis (PEP) }\end{array}$ & $\begin{array}{l}\text { People living with HIV } \\
\text { Gay/bi/trans and other men } \\
\text { who have sex with men }\end{array}$ & $\begin{array}{l}\text { Education activities include group } \\
\text { workshops/presentations and one- } \\
\text { on-one education through outreach } \\
\text { targeted to priority populations } \\
\text { Support sessions provided to clients } \\
\text { at Ontario's community-based } \\
\text { HIV organizations }\end{array}$ & $\begin{array}{l}\text { Increased use of PEP for HIV by } \\
42 \% \text { [62] }\end{array}$ \\
\hline Supportive housing & People living with HIV & $\begin{array}{l}\text { HIV supportive housing programs } \\
\text { across Ontario: Fife House \& } \\
\text { McEwan Housing and Support } \\
\text { Services (Toronto), AIDS Niagara } \\
\text { (St. Catherines), Bruce House } \\
\text { (Ottawa), John Gordon Home- } \\
\text { Regional HIV/AIDS Connection } \\
\text { (London), and Abercrombie Place- } \\
\text { ARCH (Guelph) }\end{array}$ & $\begin{array}{l}\text { Homeless/ marginally-housed } \\
\text { people living with HIV were } \\
\text { associated with poorer HAART } \\
\text { access/adherence or treatment } \\
\text { outcomes [63] } \\
\text { Housing status reduces needle } \\
\text { sharing (OR } 0.37,95 \% \text { CI } \\
\text { 0.15-0.81) and unprotected sex } \\
\text { (OR } 0.39,95 \% \text { CI } 0.18-0.84 \text { ) } \\
\text { [64] }\end{array}$ \\
\hline
\end{tabular}

the effectiveness of each type of intervention. It is worth noting that the services offered by Ontario's communitybased HIV organizations differ from the HIV/STI prevention services offered by the province's public health units, which focus mainly on providing sexual health clinics for the general population, testing services, and tracing the contacts of people newly diagnosed with HIV or another STI. While both community-based HIV organizations and public health units distribute condoms, public health condom distribution programs are focused mainly on youth with a primary goal of preventing STIs and teenage pregnancy, while community-based HIV organizations focus on condom distribution to populations most at risk of HIV.

In Ontario, community-based HIV organizations are primarily funded by the AIDS Bureau of the Ontario Ministry of Health and Long-term Care (since 1987) and the AIDS Community Action Program (ACAP) of the Public Health Agency of Canada (since 1993). Community-based HIV organizations also seek funding from other federal, provincial, regional and local government health programs, from foundations, and from the general public [13, 14]. In general, about $58 \%$ of their funding comes from the AIDS Bureau, $8 \%$ from ACAP, $21 \%$ from other government health programs and $13 \%$ from other sources $[13,14]$.

\section{Data Sources and Analytic Framework}

Our analytic framework was based on well-established methods used to evaluate U.S. investments in HIV prevention strategies [15-21]. Analyses were conducted from the payer perspective. Ontario HIV transmission rates were estimated from Ontario HIV surveillance reports dating to 1986, the first full year in which HIV testing results became available [24]. Lifetime HIV treatment costs in Canada were obtained from the scientific literature [25]. Expenditures of community-based HIV prevention programs were obtained from budgetary costs submitted by all community-based organizations [13]. All estimated costs are reported in 2011 Canadian dollars using the corresponding consumer price indices (CPI) [26] and a discounted rate of $3 \%$ [27, 28].

We first quantified the historical impacts of communitybased HIV programs by estimating the number of HIV cases averted and the associated estimated cost savings to the Ontario health care system. We then estimated the financial return-on-investment ratio for Ontario's investment in community-based HIV programs from 2005 to 2011.

In our analysis, we recognize that community-based HIV prevention programs are not the only interventions that influence infection rates. General programs offered by public health units contribute as do biomedical treatment programs (i.e., the use of antiretroviral therapy, which reduces infectiousness).

To estimate the number of HIV infection cases averted by province-wide community-based HIV programs, we first used the differential in HIV transmission rates between Ontario and a comparator (which was assumed to not have Ontario's HIV prevention programs) to estimate the total number of HIV infections averted by both biomedical (i.e., antiretroviral therapy-related) and non-biomedical (i.e. community-based and public health) interventions in Ontario. The HIV transmission rate of the comparator was assumed to be the mean of Ontario's incidence rates from 1987 (when community-based and public health programs began) to 1996 (1 year before highly active antiretroviral therapy [HAART] became available). The comparator was Ontario itself-only assuming a period with no HIV 
prevention programs or very minimal programming-so that systematic differences between Ontario and the comparator were minimized. Our assumption of the comparator's HIV transmission rate was conservative because we used average rates from a period when public health and community-based programs were already in place.

Once we had the total number of HIV cases averted by Ontario's HIV prevention programs, we factored in the number of cases averted by type of intervention based on literature-based proportions during both the pre-HAART and post-HAART eras. During the pre-HAART era (before 1997), we assumed that all the HIV infection cases averted were due to province-wide community-based and public health programs. We also assumed (conservatively) that $30 \%$ of the HIV cases averted were due to the effort of Ontario's STI public health control programs, although a recent mathematical model has found that the probability of HIV infections averted due to STI preventions (cofactors and STI screening) was about $15 \%[23,29]$.

During the post-HAART era (1997 and onwards), we assumed that biomedical interventions were responsible for averting $75 \%$ of new infections while non-biomedical programs (public health and community-based programs) helped to avert $25 \%$ of new diagnoses. Our assumptions are very conservative because the effect of the introduction of antiretroviral therapy on HIV prevention in developed countries was estimated at $25 \%[23,30]$ and the theoretical efficacy (universal annual screening, immediate linkage to care, universal ART and perfect adherence) of implementing HAART-related interventions is unlikely to be achieved in real world settings. In addition, a recent mathematical model demonstrated a few counter-factual scenarios in a simple world for HIV epidemics based on having only ART and condoms (the key representation of non-ART intervention) for HIV prevention. If no ART were introduced and all condom use ceased, the mean HIV incidence would have increased by 0.36 and 2.25 respectively [30]. These scenarios give a rough idea that approximately 14 and $86 \%$ of the total decrease of HIV incidence was attributed to ART introduction and to condom use respectively [30]. For the total number of cases averted by non-biomedical interventions, we assumed that about $30 \%$ were averted by the efforts of public health programs for STI prevention.

We estimated savings in Canadian health care system costs by multiplying the number of HIV infection cases averted (attributed to community-based HIV programs) by the lifetime treatment cost associated with HIV infection. Annual direct costs for treating HIV were estimated by conducting a literature review for cost-of-illness studies published between January 1, 1986 and December 31, 2012 using HealthSTAR, Medline, PubMed, EMBASE, Cochrane databases and grey literature (i.e., government or non-government reports, theses, dissertations, and conference proceedings). Search terms included: "cost of illness," "costs," "health expenditures," "cost analysis," "economic value of life," "direct cost," and "medical cost." We included studies: (a) with HAART as a routine clinical treatment; (b) from the Canadian health care system; and (c) concerning people living with HIV in general. Seven academic articles [31-35] and grey literature reports $[36,37]$ were found. Four articles $[31,32,34,35]$ were not related to estimating direct medical costs and the methods in two reports [36, 37] were not rigorous. Our estimate for the direct costs to treat HIV was based on a retrospective cohort study conducted in Alberta, Canada by Krentz et al. [33]. The mean treatment cost per patient per month (PPM) was estimated as $\$ 1,159$ (in 2005 Canadian dollars), varying from $\$ 979$ to \$2,687 PPM depending on the stage of HIV infection [33]. Therefore, using the corresponding CPIs, the mean treatment cost per patient per year was estimated as $\$ 13,908$ (in 2005 Canadian dollars) (calculated as $\$ 1,159 \times 12$ months). Considering the type of drug therapy and CD4 counts when first infected, the number of years on ART was assumed to be between 19 and 32 years from the time of infection $[1,38,39]$. Using a discount rate of $3 \%[27,28]$, the present value of the mean lifetime treatment cost for HIV infection in Canada was approximately $\$ 256,090$ per patient in 2005 Canadian dollars, varying from $\$ 213,123$ to $\$ 297,475$. Using the corresponding CPIs [26], the present value of the mean lifetime treatment cost for HIV infection is $\$ 286,965$ in 2011 Canadian dollars, varying from $\$ 238,817$ to $\$ 333,339$.

We estimated the financial return-on-investment (ROI) ratio [40, 41] for Ontario's investments in communitybased HIV programs (from 2005 to 2011) by dividing the net present value of net savings in health care costs from averted HIV cases by the total investments in communitybased HIV programs, in 2011 dollars, discounted at $3 \%$. Completed budgetary data for community-based HIV programs were not available prior to 2005 .

\section{Sensitivity Analyses}

Several one-way sensitivity analyses were conducted to examine the impact of assumptions made in analyzing the number of HIV infections averted and the savings attributed to community-based HIV programs in the health care system. First, we assessed the impact by assuming that the HIV transmission rate of the comparator was the largest or the smallest transmission rate from 1987 to 1996 (the preHAART era) in Ontario. Second, we reduced our assumed proportion of averted HIV infections that were attributed to public health STI programs from $30 \%$ to a more realistic proportion of $15 \%$ [23, 29]. Third, we reduced our assumed proportion of the averted HIV infections that were attributed to the introduction of antiretroviral therapy from $75 \%$ to a more realistic proportion of $25 \%$ [23, 30]. Fourth, we assessed the impact by assuming the discount 
rate of $5 \%$ for deriving the present value of lifetime HIV treatment costs. Finally, we simultaneously varied two or more of our assumptions to examine the impact on our results.

\section{Results}

Table 2 presents the estimated number of new HIV cases averted by all types of HIV prevention strategies in Ontario from 1987 to 2011. Overall, during this period and in contrast to the comparator (without HIV prevention strategies in place), we estimated that approximately 70,279 new HIV infection cases were averted by Ontario's HIV prevention strategies. When stratified by intervention type, we estimated that about 46,462, 7145 and 16,672 new HIV cases were averted by biomedical, public health, and community-based HIV programs respectively during this period (Fig. 1).

In terms of the corresponding economic impacts, we estimated that a total of $\$ 25.3$ billion CAD (range \$18.8-29.4 billion) (in 2011 dollars, 1 USD $=0.99$ CAD [42]) was saved in the Ontario health care system (see Fig. 1) from 1987 to 2011. Based on type of intervention,

Table 2 HIV incidence, prevalence, and transmission rate and total number of HIV infections averted (in cases) in Ontario (1987-2011)

\begin{tabular}{|c|c|c|c|c|c|c|c|}
\hline \multirow[t]{2}{*}{ Year } & \multicolumn{3}{|l|}{ Ontario } & \multirow{2}{*}{$\begin{array}{l}\text { Comparator }^{\mathrm{a}} \\
\text { HIV } \\
\text { transmission }_{\text {rate }^{\mathrm{b}}(4)}\end{array}$} & \multicolumn{2}{|l|}{ New HIV infection cases } & \multirow{2}{*}{$\begin{array}{l}\text { Total HIV } \\
\text { infection averted } \\
(\mathrm{C})=(\mathrm{A})-(\mathrm{B})\end{array}$} \\
\hline & $\begin{array}{l}\text { HIV } \\
\text { incidence } \\
(1)\end{array}$ & $\begin{array}{l}\text { HIV } \\
\text { prevalence in } \\
\text { previous year } \\
\text { (2) }\end{array}$ & $\begin{array}{l}\text { HIV } \\
\text { transmission } \\
\text { rate }^{\mathrm{b}}(3)\end{array}$ & & $\begin{array}{l}\text { Comparator } \\
(A)=[(4) \times(2)] \div 100\end{array}$ & $\begin{array}{l}\text { Ontario } \\
(B)=[(3) \times(2)] \div 100\end{array}$ & \\
\hline 1987 & 1546 & 1546 & 53.1 & 20.8 & 321.6 & 821.3 & 0.0 \\
\hline 1988 & 1442 & 4352 & 33.1 & 20.8 & 905.3 & 1442.0 & 0.0 \\
\hline 1989 & 1702 & 6054 & 28.1 & 20.8 & 1259.4 & 1702.0 & 0.0 \\
\hline 1990 & 2062 & 8116 & 25.4 & 20.8 & 1688.3 & 2062.0 & 0.0 \\
\hline 1991 & 1822 & 9938 & 18.3 & 20.8 & 2067.3 & 1822.0 & 245.3 \\
\hline 1992 & 1797 & 11735 & 15.3 & 20.8 & 2441.1 & 1797.0 & 644.1 \\
\hline 1993 & 1477 & 13212 & 11.2 & 20.8 & 2748.4 & 1477.0 & 1271.4 \\
\hline 1994 & 1304 & 14516 & 9.0 & 20.8 & 3019.7 & 1304.0 & 1715.7 \\
\hline 1995 & 1314 & 15830 & 8.3 & 20.8 & 3293.0 & 1314.0 & 1979.0 \\
\hline 1996 & 1034 & 16864 & 6.1 & 20.8 & 3508.1 & 1034.0 & 2474.1 \\
\hline 1997 & 924 & 17788 & 5.2 & 20.8 & 3700.3 & 924.0 & 2776.3 \\
\hline 1998 & 953 & 18741 & 5.1 & 20.8 & 3898.6 & 953.0 & 2945.6 \\
\hline 1999 & 889 & 19630 & 4.5 & 20.8 & 4083.5 & 889.0 & 3194.5 \\
\hline 2000 & 886 & 20,516 & 4.5 & 20.8 & 4267.8 & 923.2 & 3344.6 \\
\hline 2001 & 957 & 21,473 & 4.6 & 20.8 & 4466.9 & 987.8 & 3479.1 \\
\hline 2002 & 1,132 & 22,605 & 5.2 & 20.8 & 4702.4 & 1175.5 & 3526.9 \\
\hline 2003 & 1,164 & 23,769 & 4.8 & 20.8 & 4944.5 & 1140.9 & 3803.6 \\
\hline 2004 & 1,085 & 24,854 & 4.9 & 20.8 & 5170.2 & 1217.8 & 3952.4 \\
\hline 2005 & 1,106 & 25,960 & 4.4 & 20.8 & 5400.3 & 1142.2 & 4258.0 \\
\hline 2006 & 1,132 & 27,092 & 4.3 & 20.8 & 5635.8 & 1165.0 & 4470.8 \\
\hline 2007 & 1,049 & 28,141 & 3.9 & 20.8 & 5854.0 & 1097.5 & 4756.5 \\
\hline 2008 & 1,102 & 29,243 & 3.9 & 20.8 & 6083.2 & 1140.5 & 4942.7 \\
\hline 2009 & 999 & 30,242 & 3.4 & 20.8 & 6291.0 & 1028.2 & 5262.8 \\
\hline 2010 & 1,023 & 31,265 & 3.3 & 20.8 & 6503.8 & 1023.0 & 5480.8 \\
\hline 2011 & 946 & 32,211 & 2.9 & 20.8 & 6700.6 & 946.0 & 5754.6 \\
\hline & & & & Total & $99,055.1$ & $30,628.9$ & $70,278.9$ \\
\hline
\end{tabular}

a HIV transmission rate of the comparator was assumed to be the mean of Ontario's incidence rates from 1987 to 1996 [i.e., a time when the investments of community-based and public health programs had begun (1987) and before the introduction of highly active antiretroviral therapy (HAART) (1996)]. Our comparator was Ontario itself, so systematic differences between Ontario and the comparator were minimized. Our assumption of the comparator's HIV transmission rate was conservative because we used average rates during a period when public health and community-based programs were already in place

b Per 100 persons living with HIV 

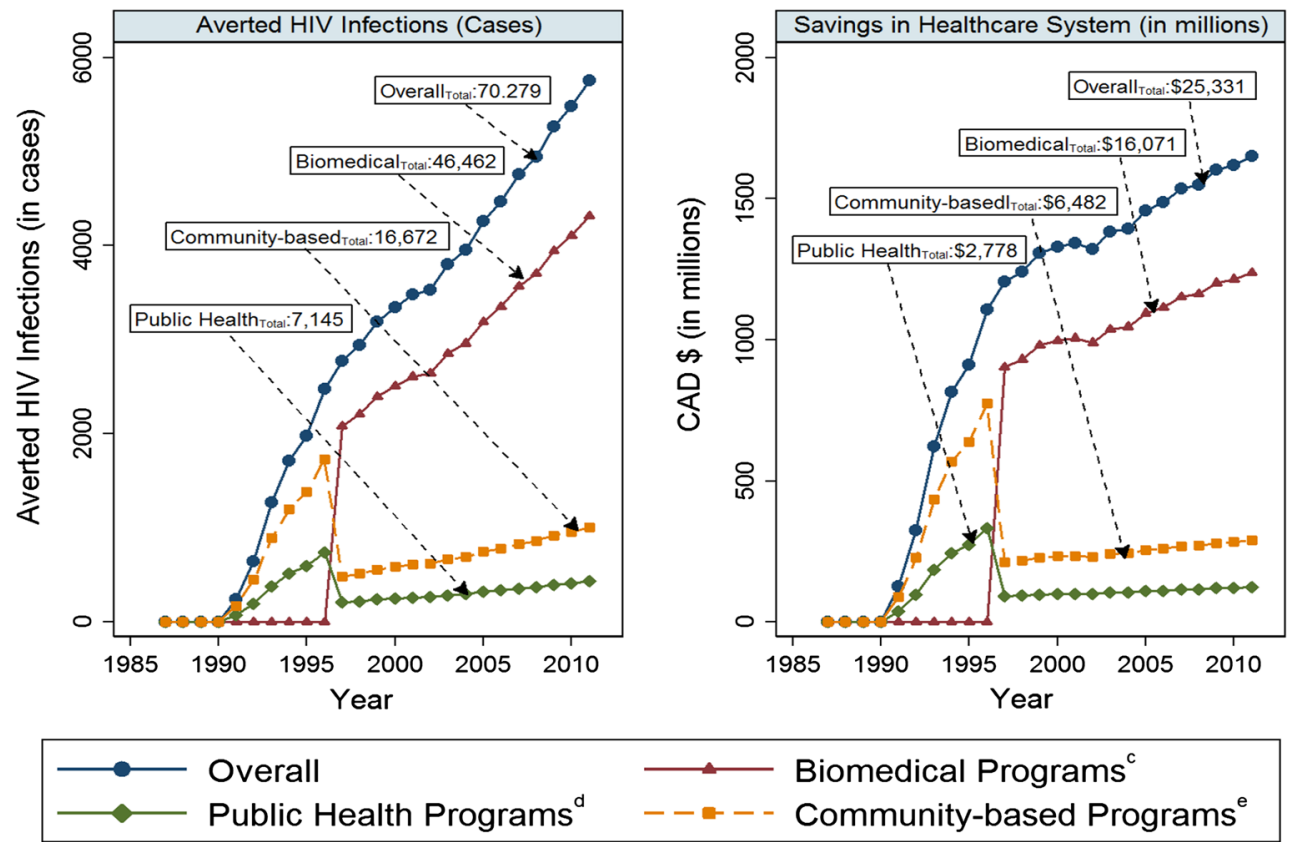

Fig. 1 Estimated number of HIV infections averted ${ }^{\mathrm{a}}$ and savings to the Canadian health care system (in millions) ${ }^{\mathrm{b}}$ by intervention type in Ontario (1987-2011). Notes (a) number of HIV infection cases averted by province-wide community-based HIV prevention programs was estimated in two steps. We first used the differential in HIV transmission rates between Ontario and a comparator to estimate the total number of HIV infections averted by both biomedical (i.e. antiretroviral therapy-related) and non-biomedical (i.e. communitybased and public health program) interventions in Ontario. The HIV transmission rate of the comparator was assumed to be the mean of Ontario's incidence rates from 1987 to 1996 (when investments in community-based and public health programs had begun but HAART was not yet in place). Once we had the total number of HIV cases averted by the Ontario's HIV prevention programs, we factored in the number of cases averted by type of intervention based on literaturebased proportions. We assumed conservatively that $30 \%$ of the HIV cases averted were due to the effort of Ontario's STI public health control programs (although results of a recent mathematical model suggest that the probability of HIV infections averted due to STI preventions [cofactors and STI screening] was about $15 \%$ ) [23, 29]. During the post-HAART era (1997 and onwards), we assumed the proportion of HIV infection cases averted by biomedical programs as
$75 \%$ of the total number of the cases averted and by non-biomedical programs (public health and community-based programs) as $25 \%$ of the total cases averted [23,30]. Our comparator was Ontario itself, so systematic differences between Ontario and the comparator were minimized. Our assumption of the comparator's HIV transmission rate was conservative because we used average rates during a period when public health and community-based programs were already in place. (b) Savings in Canadian healthcare system costs were estimated by multiplying the number of HIV infection cases averted (attributed to community-based HIV programs) by the lifetime treatment cost associated with HIV infection. Mean lifetime medical costs were estimated as \$286,965 (range \$238,817-\$333,339) per patient in 2011 Canadian dollars. All estimated savings are reported in 2011 CAD using the corresponding consumer price indices in Ontario [26]. (c) Biomedical interventions were assumed to be related to the introduction of antiretroviral therapy. (d) Public health programs were assumed to be mainly focused on sexually transmitted infections (STIs). These programs included a wide range of initiatives, e.g. medications to treat STIs, education and outreach programs, needle exchange programs, sexual health hotlines, etc. (e) Community-based programs were assumed to be non-biomedical interventions excluding public health sexually transmitted infection control programs [26] about \$16.1 billion CAD (range \$11.9-18.7 billion), \$2.8 billion CAD (range $\$ 2.1-3.2$ billion), and $\$ 6.5$ billion CAD (range $\$ 4.8-7.5$ billion) were saved by biomedical, public health, and community-based HIV strategies respectively (see Fig. 1).

Table 3 presents the results of the financial ROI ratio for community-based HIV programs in Ontario from 2005 to 2011. Completed budgetary data for community-based HIV programs were not available prior to 2005. During the period from 2005 to 2011, approximately $\$ 328$ million (in 2011 dollars, discounted by $3 \%$ ) were invested in community-based HIV programs and these programs helped to save about $\$ 1.9$ billion (in 2011 dollars, discounted by $3 \%$ ). Thus, the financial ROI ratio was about 4.8 (i.e., a dollar invested in community-based HIV programs would save the Ontario health care system approximately $\$ 5$ dollars in treatment costs).

Figure 2 presents the results of a series of sensitivity analyses for the impacts on health care savings attributed to community-based HIV programs. The results were sensitive to our assumptions. By assuming that the HIV transmission rate of the comparator was the largest HIV transmission rate in Ontario during the pre-HAART era, the health care savings increased by approximately $278 \%$ 
Table 3 Financial return on investment from Ontario's investment in community-based programs for HIV infections (2005-2011)

\begin{tabular}{|c|c|c|c|c|c|}
\hline \multirow[t]{2}{*}{ Year } & \multirow{2}{*}{$\begin{array}{l}\text { Savings in Canadian } \\
\text { health care system by } \\
\text { community-based } \\
\text { programs }^{\mathrm{a}}\end{array}$} & \multicolumn{4}{|c|}{ Investments in community-based HIV programs } \\
\hline & & AIDS Bureau ${ }^{b}$ & $\mathrm{ACAP}^{\mathrm{c}}$ & $\begin{array}{l}\text { Other } \\
\text { governmental }^{\mathrm{d}}\end{array}$ & Others ${ }^{\mathrm{e}}$ \\
\hline 2005 & $\$ 213,833,757$ & $\$ 12,644,074$ & $\$ 2,534,540$ & $\$ 8,118,491$ & $\$ 10,222,525$ \\
\hline 2006 & $\$ 224,518,625$ & $\$ 13,607,252$ & $\$ 3,323,877$ & $\$ 9,532,182$ & $\$ 10,037,582$ \\
\hline 2007 & $\$ 238,864,805$ & $\$ 13,830,988$ & $\$ 2,441,225$ & $\$ 9,948,038$ & $\$ 9,904,051$ \\
\hline 2008 & $\$ 248,218,737$ & $\$ 16,567,895$ & $\$ 3,252,240$ & $\$ 11,584,297$ & $\$ 10,968,874$ \\
\hline 2009 & $\$ 264,291,987$ & $\$ 17,698,104$ & $\$ 3,796,024$ & $\$ 12,058,316$ & $\$ 7,962,258$ \\
\hline 2010 & $\$ 275,241,483$ & $\$ 20,083,701$ & $\$ 3,564,936$ & $\$ 14,223,361$ & $\$ 10,125,239$ \\
\hline 2011 & $\$ 288,990,894$ & $\$ 20,338,042$ & $\$ 3,859,085$ & $\$ 13,106,427$ & $\$ 9,719,275$ \\
\hline Total & $\$ 1,753,960,288$ & $\$ 114,770,056$ & $\$ 22,771,927$ & $\$ 78,571,112$ & $\$ 68,939,804$ \\
\hline \multicolumn{5}{|c|}{ Present value of total savings in Canadian health care system (2005-2011) (in 2011 dollars, discounted by $3 \%)^{\mathrm{f}}$ (A) } & $\$ 1,908,564,059$ \\
\hline \multicolumn{5}{|c|}{ Present value of investments in community-based HIV programs (2005-2011) (in 2011 dollars, discounted by $3 \%)^{\mathrm{f}}(\mathrm{B})$} & $\$ 327,793,439$ \\
\hline \multicolumn{5}{|c|}{ Financial return on investment ratio $(\mathrm{C})=[(\mathrm{A})-(\mathrm{B})] /(\mathrm{B})$} & 4.8 \\
\hline
\end{tabular}

a Savings in Canadian health care system costs were estimated by multiplying the number of HIV infection cases averted (attributed to community-based HIV programs) by the lifetime treatment cost associated with HIV infection. Mean lifetime medical costs were estimated as $\$ 286,965$ (range \$238,817-\$333,339) per patient in 2011 Canadian dollars. All estimated savings are reported in 2011 CAD using the corresponding consumer price indices in Ontario [26]

b AIDS Bureau of the Ontario Ministry of Health and Long-term Care (MOHLTC)

c AIDS Community Action Program (ACAP) managed by the Public Health Agency of Canada Regional Offices

d Other governmental funding includes other federal, provincial, regional, and municipal-level funding sources

e Other sources includes charitable donations, fundraising, United Way, and others

f Reported present value in 2011 dollars using the corresponding consumer price indices [26] and a discount rate of $3 \%$

(see case \#1). Second, assuming that the HIV transmission rate of the comparator was the smallest HIV transmission rate in Ontario during the pre-HAART era, the savings were reduced by approximately $95 \%$ (see case \#2). Third, by assuming a more realistic proportion $(15 \%)$ of averted HIV infections attributed to public health STI programs, the savings increased by $21 \%$ (see case \# 3). Fourth, by assuming the effect of the introduction of the antiretroviral therapy on HIV prevention at a more realistic proportion of $25 \%$, the savings were increased by approximately $151 \%$ (see case \#4). Fifth, when assuming the discount rate of $5 \%$ for deriving the present value of the lifetime treatment cost for HIV, the savings increased by $386 \%$ (see case \#5). Finally, by changing two to three assumptions simultaneously, the changes in savings attributed to communitybased HIV programs varied from $-95 \%$ to $+774 \%$ (see cases \#6-22).

\section{Discussion}

Our macro-level analysis is the first study to attempt to quantify the historical and economic impacts of provincewide, community-based programs for HIV prevention in Ontario. From 1987 to 2011, our results show that these programs might have helped to avert approximately 16,672 new cases of HIV infection, and saved a total of $\$ 6.5$ billion (range 4.8-7.5B) for the Ontario health care system (in 2011 Canadian dollars). We also showed that communitybased HIV programs were cost-saving because every $\$ 1$ invested in these programs from 2005 to 2011 saved about $\$ 5$ in treatment costs. Nonetheless our evaluation was conducted at macro-level. It did not attempt to assess which types of community-based prevention interventions were most effective.

Our results are consistent with similar studies in other jurisdictions. Our projection of the number of HIV infections that would occur if HIV prevention interventions were not in place is comparable to the U.S. CDC estimates [17-21]. In Ontario, the HIV prevention strategy has relied heavily on community actions and programs since the beginning of the epidemic [43]. Similarly, Australian researchers have found that community-based HIV prevention programs/actions have had a remarkable impact on reducing HIV incidence [44]. Community-based HIV prevention in Australia has been credited as a "public health milestone of global importance" in reducing HIV cases in the past two decades [44]. This type of data on the cost saving potential of investments in community-based programs may be particularly helpful to the Ontario health care system, which-unlike the mixed private-public funded system in the U.S.-is predominantly a single 

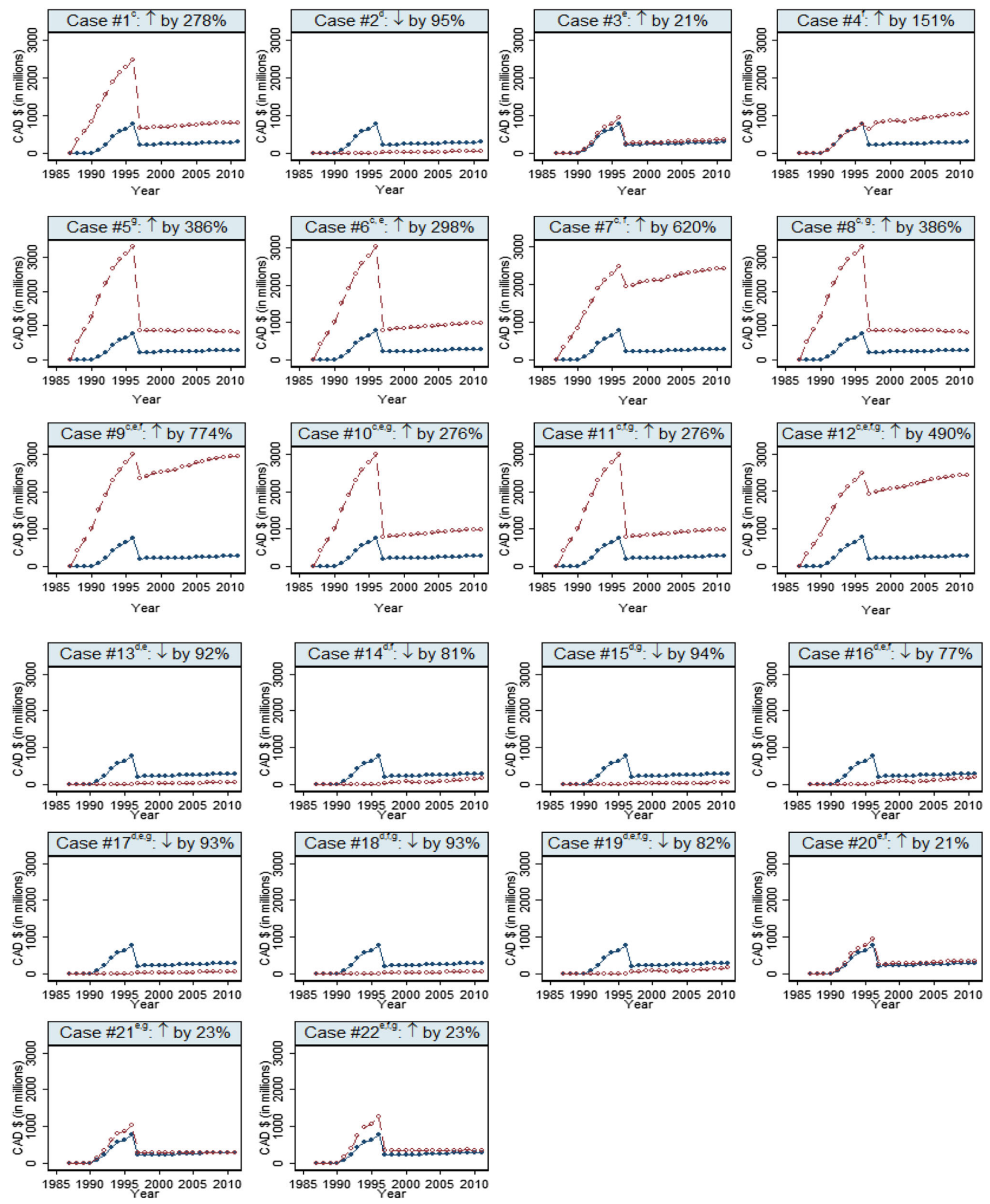

Base case $\quad--\theta--$ Varying one or more assumptions 
4Fig. 2 Sensitivity analyses ${ }^{\mathrm{a}}$ for examining impacts on savings ${ }^{\mathrm{b}}$ in Canadian health care systems attributed to community-based programs $^{\mathrm{c}}$ for HIV Prevention through varying one or more assumptions. Notes (a) Varies one or more assumptions simultaneously. (b) Medical system savings are calculated based on the estimated mean of lifetime medical costs, or $\$ 286,965$ (range $\$ 238,817-\$ 333,339$ ) per patient in 2011 Canadian dollars. All estimated savings are reported in 2011 CAD using the corresponding consumer price indices in Ontario [26]. (c) Community-based programs were assumed to be non-biomedical interventions excluding public health sexually transmitted infection control programs. Non-biomedical interventions were assumed to be mainly education, outreach, and social behavioural programs that were not related to the introduction of antiretroviral therapy (e.g. condom distribution programs, community outreach, needle exchange programs, sexual education, programs for improving antiretroviral adherence or increasing awareness of the use of post-exposure prophylaxis, etc.). HIV transmission rate of the comparator was the largest transmission (53.1 per 100 persons living with HIV) rate from 1987 to 1996 (pre-HAART era) in Ontario. (d) HIV transmission rate of the comparator was the smallest transmission (6.1 per 100 persons living with HIV) rate from 1987 to 1996 (pre-HAART era) in Ontario. (e) A more realistic proportion (15\%) of averted HIV infections were assumed to be attributable to public health STI programs [23, 29]. (f) We assumed the effect of the introduction of antiretroviral therapy on HIV prevention at a realistic proportion of $25 \%$ [23, 30]. (g) We assumed the discount rate of $5 \%$ for deriving the present value of lifetime HIV treatment costs

(government) payer system. Savings from investments in prevention programs accrue back to system, where they can be reallocated to other health priorities.

Our results for the financial ROI ratio for communitybased HIV programs were comparable to findings of ROI ratios in mental health promotion programs and other public health strategies, which ranged from \$1 to \$25 [4547]. Our ROI estimate was conservative because we only included savings in direct health care costs as opposed to the broader health and social benefits of averted HIV infections.

Over the past 28 years, Ontario's community-based HIV programs have made significant efforts to reach populations and communities at risk, and to develop the kind of meaningful relationships and programs that lead to good health outcomes, including a reduction in new infections $[13,14]$. Even in the post-antiretroviral therapy era, with its strong focus on treatment-related prevention, more and more evidence is showing that biomedical and social behavioral interventions are essential complements to each other in order to deliver effective combination prevention programs [9, 23, 30, 48-51]. Social behavioural and structural interventions, together with community actions, are important at each step to help people living with HIV achieve virologic suppression, including interventions that respond to stigma, engage patients in HIV testing, initiate ARV medication, maintain long-term adherence to ARV, and retain patients in HIV care [49-53]. Given the comprehensive nature of community-based HIV prevention programs in Ontario and the emerging evidence on the effectiveness of combination approaches to prevention, our findings are likely a conservative estimate of the impact of Ontario's investment in community-based programs for HIV prevention.

Our study has several limitations. First, the economic evaluation analyses relied on aggregate-level data and the ecological analysis might not have allowed our analysis to consider heterogeneity among individuals or to control for other confounding factors over time. However, these types of methods and analytic approaches have been previously used in many U.S. studies to successfully evaluate their HIV prevention programs and strategies [15-21].

Second, we made the causal assumption in our analysis that community-based HIV prevention programs in Ontario can reduce new HIV infections. However, this is a reasonable assumption given that many of the communitybased HIV prevention programs in Ontario are evidencebased, and the effectiveness of these types of programs have been shown in the literature as summarized in Table 1 [2, 4, 5, 7, 8, 54-60]. In addition, an outcomes evaluation report, based on sound qualitative methods, found that Ontario's community-based HIV programs are effective in reaching vulnerable and marginalized populations, increasing awareness and knowledge of HIV transmission and consequences, reducing risky behaviour for HIV infection, and increasing linkage to HIV care, support and treatment [14]. The report also concluded that successful HIV prevention outcomes are likely to be achieved by effective collaboration among healthcare providers, social services and community-based programs [14]. Future research should assess the effectiveness and cost-effectiveness of specific prevention programs at the individual level in community-based settings.

Third, we compared the yearly HIV transmission rate to the mean of Ontario's incidence rates from 1987 to 1996 in order to estimate the total number of HIV infections averted by both biomedical (i.e. antiretroviral therapy-related) and non-biomedical (i.e. community-based and public health program) interventions in Ontario. Our comparator is a reasonable and conservative choice. During this period, investments in community-based and public health programs had begun and HAART was not yet in place. As well, our comparator was Ontario itself, so systematic differences between Ontario and the comparator were minimized.

Fourth, our results were shown to be sensitive to our assumptions. By changing one or more assumptions, the changes in saving attributed to community-based HIV programs varied from -95 to $+774 \%$ (see Fig. 2). Nevertheless, all negative changes in our savings estimate were due to the fact that we varied the HIV transmission rate of the comparator to the lowest HIV transmission rate in Ontario during the pre-HAART era (see Table 2). 
However, the lowest HIV transmission rate occurred in 1995 (see Table 2), when most of public health and community-based HIV programs were well-established. In addition, our assumption of the comparator's HIV transmission rate was conservative because we used average rates from a period when public health and communitybased HIV programs were already in place. Furthermore, as already discussed, we assumed the proportion of HIV infection cases averted by biomedical programs at the theoretical efficacy rate of $75 \%$, which is high given that the estimated effect of the introduction of antiretroviral therapy in the real world is $25 \%[23,30]$. Moreover, we assumed that $30 \%$ of the HIV cases averted were due to the effort of Ontario's STI public health control programs, even though the results of a recent mathematical model suggest a rate of about $15 \%$ [23, 29].

Despite these limitations, our results shed some light on investments made in community-based HIV prevention programs in Ontario and how these investments have reduced HIV infections and health care system costs. Given that an effective vaccine for HIV is not yet available [61] and that the HIV epidemic is far from over [24, 25], continued investments in a combination of effective and evidence-based programs is essential, particularly in the postHAART era. A more holistic approach that strategically and effectively combines evidence-based community actions, public health, biomedical, structural, and sociobehavioural efforts will likely yield the most significant impact on reducing new HIV infections [49-53].

Future research should provide individual-level economic evidence of the impact of investments in community-based HIV prevention programs to help both provincial and federal governments make strategic decisions about how to have the most impact on the HIV epidemic in Ontario, especially in an environment of constrained health care resources.

\begin{abstract}
Acknowledgments The authors gratefully thank their OHTN colleagues for frontline AIDS service organization knowledge support (Maria Hatzipantelis) and data management support (Jaime-Lee Webster, Michelle Song, and Carlos Joseph), and for editing and knowledge translation support (Emily White). The authors would also like to acknowledge the support they obtained from all frontline AIDS service organizations, AIDS and Hepatitis C Programs, the Ontario Ministry of Health and Long-Term Care and the Public Health Agency of Canada, Ontario Region for data collection and approvals for the use of the data sources in this study.
\end{abstract}

\section{Conflict of interests None.}

Open Access This article is distributed under the terms of the Creative Commons Attribution 4.0 International License (http://creativecommons.org/licenses/by/4.0/), which permits unrestricted use, distribution, and reproduction in any medium, provided you give appropriate credit to the original author(s) and the source, provide a link to the Creative Commons license, and indicate if changes were made.

\section{References}

1. Farnham PG, Gopalappa C, Sansom SL, Hutchinson AB, Brooks JT, Weidle PJ, et al. Updates of lifetime costs of care and qualityof-life estimates for HIV-infected persons in the United States: late versus early diagnosis and entry into care. J Acquir Immune Defic Syndr. 2013;64:183-9. Available from: http://www.ncbi. nlm.nih.gov/pubmed/23615000. Cited 17 Apr 2015.

2. Aspinall EJ, Nambiar D, Goldberg DJ, Hickman M, Weir A, Van Velzen E, et al. Are needle and syringe programmes associated with a reduction in HIV transmission among people who inject drugs: a systematic review and meta-analysis. Int J Epidemiol. 2014;43:235-48. Available from: http://www.ncbi.nlm.nih.gov/ pubmed/24374889. Cited 16 Apr 2015.

3. Crepaz N, Lyles CM, Wolitski RJ, Passin WF, Rama SM, Herbst $\mathrm{JH}$, et al. Do prevention interventions reduce HIV risk behaviours among people living with HIV? A meta-analytic review of controlled trials. AIDS. 2006;20:143-57. Available from: http:// www.ncbi.nlm.nih.gov/pubmed/16511407. Cited 16 Apr 2015.

4. Needle RH, Burrows D, Friedman SR, Dorabjee J, Touzé G, Badrieva L, et al. Effectiveness of community-based outreach in preventing HIV/AIDS among injecting drug users. Int J Drug Policy. 2005;16:45-57. Available from: http://linkinghub.else vier.com/retrieve/pii/S0955395905000964. Cited 14 Apr 2015.

5. Qiao S, Li X, Stanton B. Social support and HIV-related risk behaviors: a systematic review of the global literature. AIDS Behav. 2014;18:419-41. Available from: http://www.pub medcentral.nih.gov/articlerender.fcgi?artid=3946791\&tool=pmcen trez\&rendertype $=$ abstract. Cited 22 Mar 2015.

6. Bateganya MH, Amanyeiwe U, Roxo U, Dong M. Impact of support groups for people living with HIV on clinical outcomes. J Acquir Immune Defic Syndr. 2015;68:S368-74. Available from: http://www.ncbi.nlm.nih.gov/pubmed/25768876. Cited 16 Apr 2015.

7. LaCroix JM, Snyder LB, Huedo-Medina TB, Johnson BT. Effectiveness of mass media interventions for HIV prevention, 1986-2013. J Acquir Immune Defic Syndr. 2014;66:S329-40. Available from: http://www.ncbi.nlm.nih.gov/pubmed/25007204. Cited 16 Apr 2015.

8. Herbst JH, Beeker C, Mathew A, McNally T, Passin WF, Kay LS, et al. The effectiveness of individual-, group-, and community-level HIV behavioral risk-reduction interventions for adult men who have sex with men: a systematic review. Am J Prev Med. 2007;32:S38-67. Available from: http://www.sciencedirect. com/science/article/pii/S0749379706005551. Cited 14 Apr 2015.

9. Johnson WD, Diaz RM, Flanders WD, Goodman M, Hill AN, Holtgrave D, et al. Behavioral interventions to reduce risk for sexual transmission of HIV among men who have sex with men. Cochrane Database Syst Rev. 2008;CD001230. Available from: http://www. ncbi.nlm.nih.gov/pubmed/18646068. Cited 5 Mar 2014.

10. Charania M. Efficacy of structural-level condom distribution interventions: a meta-analysis of U.S. and international studies, 1998-2007. AIDS Behav. 2011;15:1283-97.

11. Charania MR, Marshall KJ, Lyles CM, Crepaz N, Kay LS, Koenig LJ, et al. Identification of evidence-based interventions for promoting HIV medication adherence: findings from a systematic review of U.S.-based studies, 1996-2011. AIDS Behav. 2014;18:646-60. Available from: http://www.ncbi.nlm.nih.gov/ pubmed/24043269. Cited 8 Apr 2015.

12. Willis S, Castel AD, Ahmed T, Olejemeh C, Frison L, Kharfen M. Linkage, engagement, and viral suppression rates among HIVinfected persons receiving care at medical case management programs in Washington, DC. J Acquir Immune Defic Syndr. 2013;64:S33-41. Available from:/pmc/articles/PMC3844615/ ?report $=$ abstract. Cited 16 Apr 2015. 
13. AIDS service organizations, AIDS and Hepatitis C Programs, the Ontario Ministry of Health and Long-Term Care, and the Public Health Agency of Canada, Ontario Region. Ontario Community HIV/AIDS Reporting Tool.

14. Public Health Agency of Canada. Evaluation of the Federal Initiative to Address HIV/AIDS in Canada 2008-09 to 2012-13. 2013; Available from: http://www.phac-aspc.gc.ca/about_apro pos/evaluation/reports-rapports/2013-2014/diaha-idlvs/indexeng.php.

15. Holtgrave D. Threshold analysis and programs for prevention of HIV infection. Med Decis Mak. 1995;15:311-7.

16. Holtgrave DR. Handbook of economic evaluation of HIV prevention programs. New York: Plenum Press; 1998.

17. Farnham PG, Holtgrave DR, Sansom SL, Hall HI. Medical costs averted by HIV prevention efforts in the United States, 1991-2006. J Acquir Immune Defic Syndr. 2010;54:565-7. Available from: http://www.ncbi.nlm.nih.gov/pubmed/20647830. Cited 14 Jan 2015.

18. Holtgrave DR. Costs and consequences of the US Centers for Disease Control and Prevention's recommendations for opt-out HIV testing. PLoS Med. 2007;4:e194.

19. Holtgrave DR. On the epidemiologic and economic importance of the National AIDS Strategy for the United States. J Acquir Immune Defic Syndr. 2010;55:139-42.

20. Holtgrave DR, Kim JJ, Adkins C, Maulsby C, Lindsey KD, Johnson KM, et al. Unmet HIV service needs among Black men who have sex with men in the United States. AIDS Behav. 2014;18:36-40. Available from: http://www.ncbi.nlm.nih.gov/ pubmed/23892769. Cited 6 Mar 2014.

21. Holtgrave DR, Hall HI, Wehrmeyer L, Maulsby C. Costs, Consequences and feasibility of strategies for achieving the goals of the National HIV/AIDS strategy in the United States: a closing window for success? AIDS Behav. 2012;16:1365-72. Available from: http://www.ncbi.nlm.nih.gov/pubmed/22610372. Cited 8 Aug 2012.

22. Holtgrave DR, Kates J. HIV incidence and CDC's HIV prevention budget: an exploratory correlational analysis. Am J Prev Med. 2007;32:63-7. Available from: http://www.ncbi.nlm.nih. gov/pubmed/17184960. Cited 15 Aug 2012.

23. Kessler J, Myers JE, Nucifora KA, Mensah N, Kowalski A, Sweeney M, et al. Averting HIV infections in New York City: a modeling approach estimating the future impact of additional behavioral and biomedical HIV prevention strategies. PLoS One. 2013;8:e73269. Available from: http://dx.plos.org/10.1371/jour nal.pone.0073269. Cited 6 Mar 2014.

24. Public Health Agency of Canada. HIV and AIDS in Canada: Surveillance Report to December 31, 2009-Public Health Agency of Canada. 2009.

25. Remis R, Swantee C, Liu J. Report on HIV/AIDS in Ontario 2001-2009. Toronto: Ontario Ministry of Health and Long-Term Care; 2001.

26. Statistics Canada. Consumer price index. Ottawa: Statistics Canada; 2012.

27. Drummond MF, O'Brien B, Stoddart GL, Torrance GW. Methods for the economic evaluation of health care programmes. Oxford: Oxford medical Publications, Oxford University press; 1997.

28. Gold MR, Siegel JE, Russell LB, Weinstein MC. Cost-effectiveness in health and medicine. 1st ed. New York: Oxford University Press; 1996.

29. Grosskurth H, Mosha F, Todd J, Mwijarubi E, Klokke A, Senkoro $\mathrm{K}$, et al. Impact of improved treatment of sexually transmitted diseases on HIV infection in rural Tanzania: randomised controlled trial. Lancet. 1995;346:530-6. Available from: http:// www.ncbi.nlm.nih.gov/pubmed/7658778. Cited 28 May 2015.

30. Phillips AN, Cambiano V, Nakagawa F, Brown AE, Lampe F, Rodger A, et al. Increased HIV incidence in men who have sex with men despite high levels of ART-induced viral suppression: analysis of an extensively documented epidemic. PLoS One. 2013;8:e55312. Available from: http://www.pubmedcentral.nih. gov/articlerender.fcgi?artid=3574102\&tool=pmcentrez\&render type=abstract. Cited 12 Feb 2014.

31. Levy AR, James D, Johnston KM, Hogg RS, Harrigan PR, Harrigan BP, et al. The direct costs of HIV/AIDS care. Lancet Infect Dis. 2006;6:171-7. Available from: http://www.sciencedirect.com/sci ence/article/pii/S1473309906704133. Cited Dec 232011.

32. Krentz HB, Auld MC, Gill MJ. The changing direct costs of medical care for patients with HIV/AIDS, 1995-2001. Can Med Assoc J. 2003;169:106-10. Available from: http://www.ncbi.nlm. nih.gov/pubmed/12874156. Cited 23 Dec 2011.

33. Krentz HB. Cost of medical care for HIV-infected patients within a regional population from 1997 to 2006. HIV Med. 2008;9:721-30.

34. Krentz HB, Auld MC, Gill MJ. The high cost of medical care for patients who present late $(\mathrm{CD} 4<200$ cells/microL) with HIV infection. HIV Med. 2004;5:93-8.

35. Beck EJ, Harling G, Gerbase S, DeLay P. The cost of treatment and care for people living with HIV infection: implications of published studies, 1999-2008. Curr Opin HIV AIDS. 2010;5: 215-24.

36. Albert T, Williams G. Economic burden of HIV/AIDS in Canada. Canadian Policy Research Network; 1998.

37. Dodds C, Colman R, Amaratunga C, Wilson J. The cost of HIV/ AIDS in Canada. Genuine Progress Index for Atlantic Canada; 2001.

38. Holtgrave DR, Pinkerton SD. Updates of cost of illness and quality of life estimates for use in economic evaluations of HIV prevention programs. J Acquir Immune Defic Syndr Hum Retrovirol. 1997;16:54-62.

39. Schackman BR, Gebo KA, Walensky RP, Losina E, Muccio T, Sax PE, et al. The lifetime cost of current human immunodeficiency virus care in the United States. Med Care. 2006;44:990-7. Available from: http://www.ncbi.nlm.nih.gov/pubmed/17063130. Cited 2011 Dec 23.

40. The Cabinet Office. A guide to social return on investment [Internet]. 2012. Available from: http://www.thesroinetwork.org/ publications/doc_details/241-a-guide-to-social-return-on-invest ment-2012. Cited 22 Apr 2015.

41. Edwards RT, Charles JM, Lloyd-Williams H. Public health economics: a systematic review of guidance for the economic evaluation of public health interventions and discussion of key methodological issues. BMC Public Health. 2013;13:1001. Available from: http://www.biomedcentral.com/1471-2458/13/ 1001. Cited 31 Mar 2015.

42. Bank of Canada. Annual average exchange rates [Internet]. 2011. Available from: http://www.bankofcanada.ca/rates/exchange/ annual-average-exchange-rates/.

43. Allman D, Myer T, Cockerill R. Concepts, definition, and models for community-based HIV prevention research in Canada. Canada: HIV Social, Behaviour, and Epidemiological Studies Unit; 1997.

44. Plummer D, Irwin L. Grassroots activities, national initiatives and HIV prevention: clues to explain Australia's dramatic early success in controlling the HIV epidemic. Int J STD AIDS. 2006;17:787-93.

45. Roberts G, Grimes K. Return on investment: mental health promotion and mental illness prevention. 2011. Available from: http://ccednet-rcdec.ca/en/node/12032. Cited Apr 222015.

46. Ruger JP, Emmons KM. Economic evaluations of smoking cessation and relapse prevention programs for pregnant women: a systematic review. Value Health. 2015;11:180-90. Available from: http://www.pubmedcentral.nih.gov/articlerender.fcgi?artid $=2732023 \&$ tool $=$ pmcentrez\&rendertype $=$ abstract. Cited $21 \mathrm{Apr}$ 2015. 
47. Bhaumik U, Norris K, Charron G, Walker SP, Sommer SJ, Chan $\mathrm{E}$, et al. A cost analysis for a community-based case management intervention program for pediatric asthma. J Asthma 2013;50:310-7. Available from: http://www.ncbi.nlm.nih.gov/ pubmed/23311526. Cited 21 Apr 2015.

48. Hanefeld J, Bond V, Seeley J, Lees S, Desmond N. Considerations for a human rights impact assessment of a population wide treatment for HIV prevention intervention. Dev World Bioeth. 2013. Available from: http://doi.wiley.com/10.1111/dewb.12038. Cited 11 May 2014.

49. Merson MH, O'Malley J, Serwadda D, Apisuk C. The history and challenge of HIV prevention. Lancet. 2008;372:475-88. Available from: http://www.sciencedirect.com/science/article/pii/ S0140673608608843. Cited 28 Apr 2014.

50. Padian NS, McCoy SI, Karim SSA, Hasen N, Kim J, Bartos M, et al. HIV prevention transformed: the new prevention research agenda. Lancet. 2011;378:269-78. Available from: http://www. pubmedcentral.nih.gov/articlerender.fcgi?artid=3606928\&tool= pmcentrez\&rendertype $=$ abstract. Cited 30 Apr 2014.

51. Kurth AE, Celum C, Baeten JM, Vermund SH, Wasserheit JN. Combination HIV prevention: significance, challenges, and opportunities. Curr HIV/AIDS Rep. 2011;8:62-72. Available from: http://www.pubmedcentral.nih.gov/articlerender.fcgi?artid= $3036787 \&$ tool $=$ pmcentrez\&rendertype=abstract. Cited 18 May 2014.

52. Rausch DM, Grossman CI, Erbelding EJ. Integrating behavioral and biomedical research in HIV interventions: challenges and opportunities. J Acquir Immune Defic Syndr. 2013;63(Suppl 1):S6-11.

53. Kulkarni SP, Shah KR, Sarma K V, Mahajan AP. Clinical uncertainties, health service challenges, and ethical complexities of HIV "test-and-treat": a systematic review. Am. J Public Health [Internet]. 2013;103:e14-23. Available from: http://www. ncbi.nlm.nih.gov/pubmed/23597344. Cited 13 Apr 2015.

54. Lombardo AP, Léger YA. Thinking about "Think Again" in Canada: assessing a social marketing HIV/AIDS prevention campaign. J Health Commun. 2007;12:377-97. Available from: http://www.scopus.com/inward/record.url?eid=2-s2.0-34250160 158\&partnerID=tZOtx3y1. Cited 13 Apr 2015.

55. Suthar AB, Ford N, Bachanas PJ, Wong VJ, Rajan JS, Saltzman $\mathrm{AK}$, et al. Towards universal voluntary HIV testing and counselling: a systematic review and meta-analysis of communitybased approaches. PLoS Med. 2013;10:e1001496. Available from: http://www.pubmedcentral.nih.gov/articlerender.fcgi?ar tid $=3742447 \&$ tool $=$ pmcentrez\&rendertype $=$ abstract . Cited 7 Apr 2015.
56. Charania MR, Marshall KJ, Lyles CM, Crepaz N, Kay LS, Koenig LJ, et al. Identification of evidence-based interventions for promoting HIV medication adherence: findings from a systematic review of U.S.-based studies, 1996-2011. AIDS Behav. 2014;18:646-60. Available from: http://www.ncbi.nlm.nih.gov/ pubmed/24043269. Cited 8 Apr 2015.

57. Huang Y-LA, Lasry A, Hutchinson AB, Sansom SL. A systematic review on cost effectiveness of HIV prevention interventions in the United States. Appl Health Econ Health Policy. 2014;13:149-56. Available from: http://www.ncbi.nlm.nih.gov/ pubmed/25536927. Cited 16 Apr 2015.

58. Shannon K, Bright V, Allinott S, Alexson D, Gibson K, Tyndall MW. Community-based HIV prevention research among substance-using women in survival sex work: the Maka Project Partnership. Harm Reduct J. 2007;4:20. Available from: http:// www.harmreductionjournal.com/content/4/1/20. Cited 14 Apr 2015.

59. Lombardo AP, Léger YA. Thinking about "Think Again" in Canada: assessing a social marketing HIV/AIDS prevention campaign. J Health Commun. 2007;12:377-97. Available from: http://www.ncbi.nlm.nih.gov/pubmed/17558789. Cited 13 Apr 2015.

60. Leaver CA, Allman D, Meyers T, Veugelers PJ. Effectiveness of HIV prevention in Ontario, Canada: a multilevel comparison of bisexual men. Am J Public Health. 2004;94:1181-5. Available from: http://www.pubmedcentral.nih.gov/articlerender.fcgi?ar tid $=1448418 \&$ tool $=$ pmcentre $\&$ rendertype $=$ abstract. Cited 13 Apr 2015.

61. Rolland M, Edlefsen PT, Larsen BB, Tovanabutra S, SandersBuell E, Hertz T, et al. Increased HIV-1 vaccine efficacy against viruses with genetic signatures in Env V2. Nature. 2012;490: 417-20.

62. Barash EA, Golden M. Awareness and use of HIV pre-exposure prophylaxis among attendees of a Seattle Gay pride event and sexually transmitted sisease clinic. AIDS Patient Care STDS. 2010;24(11):689-91.

63. Milloy M-J, Marshall BDL, Montaner J, Wood E. Housing status and the health of people living with HIV/AIDS. Curr HIV/AIDS Rep. 2012;9(4):364-74. Available from: http://www.pub medcentral.nih.gov/articlerender.fcgi?artid=3693560\&tool=pmcent rez\&rendertype $=$ abstract.

64. Aidala A, Cross JE, Stall R, Harre D, Sumartojo E. Housing status and HIV risk behaviors: implications for prevention and policy. AIDS Behav. 2005;9(3):251-65. Available from: http:// www.ncbi.nlm.nih.gov/pubmed/16088369. 